\title{
Binary Combination of Different Breeds of Freeze-Dried Cow Urine (FCU) with Some Plant Molluscicides against Lymnaea acuminata: Vector of Fasciolosis
}

\author{
Shiv Kumar, D. K. Singh, Vinay Kumar Singh* \\ Malacology Laboratory, Department of Zoology, DDU Gorakhpur University, Gorakhpur-273009, U.P., India
}

\begin{abstract}
Molluscicidal activity of binary combination of different breeds of freeze-dried cow urine (FCU) such as Sahiwal, Geer and Tharparkar with plant molluscicides viz Annona squamosa seed powder, Azadirachta indica oil, Ferula asafoetida root latex and Camellia sinensis against harmful snail Lymnaea acuminata have been studied. It was observed that the toxicity of binary combination (1:1) of plant molluscicides and different breeds of freeze-dried cow urine (FCU) kept for 15 days in sunlight (8h/day) and laboratory condition were toxic against $L$. acuminata. Among all combinations, the toxicity of Sahiwal freeze-dried cow urine + A. squamosa $\left(24 \mathrm{~h} \mathrm{LC}_{50}-97.27 \mathrm{mg} / \mathrm{l}\right.$ and $\left.96 \mathrm{~h} \mathrm{LC}_{50}-36.19 \mathrm{mg} / \mathrm{l}\right) \mathrm{kept}$ for 15 days in sunlight (8h/day) was higher than the Geer and Tharparkar freeze-dried cow urine. Toxicity of laboratory condition of Sahiwal freeze-dried cow urine $+A$. squamosa $\left(24 \mathrm{~h} \mathrm{LC} 50-81.40 \mathrm{mg} / 1\right.$ and $\left.96 \mathrm{~h} \mathrm{LC}_{50}-34.30 \mathrm{mg} / \mathrm{l}\right)$ was more toxic than other binary combination of cow breeds and plants molluscicides. The different breeds of cow urine under the 15 days sunlight (8h/day) and laboratory conditions freeze-dried with different plant molluscicides are potent molluscicides.
\end{abstract}

Keywords Cow Urine,FCU, Plant Molluscicides, Lymnaea acuminate, Fasciolosis, Synergist

\section{Introduction}

Fasciolosis a zoonotic disease of domestic herbivorous caused by the digenetic trematode of Fasciola hepatica and Fasciola gigantica (Singh and Agarwal, 198; Mas-Coma et al., 2005; Jigyasu and Singh, 2010). Human fasciolosis is endemic different parts of the world. In human endemic areas, fasciolosis mainly affects children and female, with fluke infecting even at very early age (Mas-Coma et al., 1999; 2009). Human infection has been reported in 51 different countries from 5 continents (Estaben et al., 1998). The incidence of fasciolosis in domestic herbivorous of Eastern Uttar Pradesh, India is very high. Singh and Agarwal (1981) reported that $94 \%$ of buffaloes slaughtered in local slaughter houses of Gorakhpur district are infected with $F$. gigantica. Fresh water snails Lymnaea acuminata act as the intermediate host of the F. hepatica and F. gigantica. One of the possible approaches to control this problem is to interrupt the life cycle of the liver fluke by eliminating the snail at threshold level. Synthetic molluscicides have been widely used for the effective control of vector snail/pest control has create the problem of acute and chronic toxicity to non target animal (Agarwal and Singh,

\footnotetext{
* Corresponding author:

vksingh_gpu@yahoo.co.in (Vinay Kumar Singh)

Published online at http://journal.sapub.org/als

Copyright (C) 2011 Scientific \& Academic Publishing. All Rights Reserved
}

1988, Shafer et al., 2005).

Some time they are toxic to near target animal may have long term detrimental effect on the environment. Bio-pesticides are use toxic eco-friendly and also reduce the pollution problems caused by conventional pesticides (Singh et al., 1996a). Cow urine has been used for a long time in India to control pest, vector and pathogen. Cow urine is known to causes weight loss, and reverses certain cardiac and kidney problems, indigestion, stomach ache, edema, etc (Krishnamurthi et al., 2004). In Ayurveda, clinical effects of cow urine were described to counter kaph and pitta dosha (Krishnamurthi et al., 2004). It has been reported that use of different preparation of cow urine and dung cause viral, bacterial \& fungal disease of plants (Sridhar 2002, Jarald et al., 2008). Kalkude et al., (2010) observed cow urine concentrate a potent antimicrobial and antihelmintic activity. Tripathi et al., (2010) has been reported that the Haryana breed cow urine have potent molluscicides and the sub lethal treatment of the cow urine powder with combination of different plant derived molluscicides caused significant reduction in fecundity hatchability and survival of snail Lymnaea acuminata. Recently, we have observed that molluscicidal activity of freeze-dried cow urine of different Indian breeds against Lymnaea acuminata (Kumar et al., 2011). In the present study describes the molluscicidal activity of different Indian breeds freeze-dried cow urine (FCU) such as, Sahiwal, Geer and Tharparkar with combination of different plant mollusci- 
cides against the harmful snail Lymnaea acuminata.

\section{Materials and Methods}

\subsection{Cow Urine Preparation}

Cow urine was collected locally Gorakhpur in sterilized bottles from green grass grazing 3- year old different Indian breeds such as Sahiwal, Geer and Tharparkar. No other food materials were given to the experimental animals.

1- Sahiwal, Geer and Tharparkar cow urine kept for 15 in sun light $8 \mathrm{~h} /$ days.

Table 1. Toxicity of freeze-dried cow urine (FCU) kept for 15 days in sunlight (8h/day) of different breeds of cow Sahiwal, Geer, Tharparkar and its binary combination (1:1) with $A$. squamosa, $C$. sinensis, F. asafoetida and A. indica against L. acuminata at different exposure period.

\begin{tabular}{|c|c|c|c|c|c|c|c|}
\hline Exposure period & Treatment & $\mathrm{LC}_{50} \mathrm{mg} / \mathrm{l}(\mathrm{w} / \mathrm{v})$ & Limits LCL- UCL & Slope value & t- ratio & g-value & Heterogeneity \\
\hline \multirow{12}{*}{$24 \mathrm{~h}$} & $S h \mathrm{CU}+A S$ & 97.27 & $81.80-134.47$ & $2.98 \pm 0.58$ & 5.15 & 0.14 & 0.21 \\
\hline & $G r \mathrm{CU}+A S$ & 148.04 & $130.70-186.16$ & $3.83 \pm 0.75$ & 5.07 & 0.14 & 0.30 \\
\hline & $T h \mathrm{CU}+A S$ & 158.06 & $136.98-210.64$ & $3.64 \pm 0.75$ & 4.81 & 0.16 & 0.18 \\
\hline & $S h \mathrm{CU}+C S$ & 161.62 & $139.91-216.26$ & $3.78 \pm 0.77$ & 4.85 & 0.16 & 0.24 \\
\hline & $G r \mathrm{CU}+C S$ & 159.09 & $139.27-205.18$ & $4.06 \pm 0.79$ & 5.11 & 0.14 & 0.23 \\
\hline & $T h \mathrm{CU}+C S$ & 150.18 & $133.03-186.94$ & $4.07 \pm 0.07$ & 5.26 & 0.13 & 0.43 \\
\hline & $S h \mathrm{CU}+F A$ & 159.22 & $138.59-209.26$ & $3.85 \pm 0.78$ & 4.94 & 0.15 & 0.22 \\
\hline & $G r \mathrm{CU}+F A$ & 183.31 & $164.36-227.26$ & $4.91 \pm 0.99$ & 4.93 & 0.15 & 0.32 \\
\hline & $T h \mathrm{CU}+F A$ & 132.87 & $121.52-151.28$ & $4.81 \pm 0.77$ & 6.24 & 0.09 & 0.22 \\
\hline & $S h \mathrm{CU}+A I$ & 118.81 & $103.93-151.24$ & $3.69 \pm 0.70$ & 5.26 & 0.13 & 0.27 \\
\hline & $G r \mathrm{CU}+A I$ & 119.30 & $104.10-152.83$ & $3.63 \pm 0.69$ & 5.23 & 0.14 & 0.17 \\
\hline & $T h \mathrm{CU}+A I$ & 120.02 & $103.45-159.79$ & $3.29 \pm 0.67$ & 4.88 & 0.16 & 0.11 \\
\hline \multirow{12}{*}{$48 \mathrm{~h}$} & $S h \mathrm{CU}+A S$ & 73.24 & $62.75-92.73$ & $2.53 \pm 0.49$ & 5.07 & 0.14 & 0.25 \\
\hline & $G r \mathrm{CU}+A S$ & 122.41 & $108.80-146.62$ & $3.24 \pm 0.68$ & 4.70 & 0.17 & 0.18 \\
\hline & $T h \mathrm{CU}+A S$ & 102.26 & $75.25-130.36$ & $2.47 \pm 0.52$ & 4.68 & 0.17 & 0.12 \\
\hline & $S h \mathrm{CU}+C S$ & 124.35 & $110.39-150.10$ & $3.27 \pm 0.68$ & 4.71 & 0.17 & 0.24 \\
\hline & $G r \mathrm{CU}+C S$ & 135.34 & $119.56-168.60$ & $3.36 \pm 0.70$ & 4.77 & 0.16 & 0.14 \\
\hline & $T h \mathrm{CU}+C S$ & 128.82 & $114.99-154.62$ & $3.51 \pm 0.70$ & 5.00 & 0.15 & 0.38 \\
\hline & $S h \mathrm{CU}+F A$ & 128.79 & $113.96-158.29$ & $3.22 \pm 0.69$ & 4.65 & 0.17 & 0.11 \\
\hline & $G r \mathrm{CU}+F A$ & 160.07 & $143.84-194.59$ & $3.80 \pm 0.84$ & 4.50 & 0.19 & 0.28 \\
\hline & Th $\mathrm{CU}+F A$ & 111.23 & $99.91-126.43$ & $3.57 \pm 0.68$ & 5.20 & 0.14 & 0.12 \\
\hline & $S h \mathrm{CU}+A I$ & 93.08 & $82.33-110.99$ & $3.11 \pm 0.62$ & 5.00 & 0.15 & 0.17 \\
\hline & $G r \mathrm{CU}+A I$ & 87.73 & $61.58-79.15$ & $3.39 \pm 0.62$ & 5.45 & 0.12 & 0.22 \\
\hline & $T h \mathrm{CU}+A I$ & 102.41 & $87.66-137.84$ & $2.52 \pm 0.61$ & 4.11 & 0.22 & 0.10 \\
\hline \multirow{12}{*}{$72 h$} & $S h \mathrm{CU}+A S$ & 52.31 & $44.35-60.67$ & $2.63 \pm 0.48$ & 5.43 & 0.13 & 0.33 \\
\hline & $G r \mathrm{CU}+A S$ & 95.29 & $80.40-108.74$ & $2.89 \pm 0.67$ & 4.30 & 0.20 & 0.28 \\
\hline & $T h \mathrm{CU}+A S$ & 90.67 & $89.03-117.07$ & $3.04 \pm 0.67$ & 4.50 & 0.18 & 0.24 \\
\hline & $S h \mathrm{CU}+C S$ & 99.96 & $87.94-112.48$ & $3.35 \pm 0.68$ & 4.93 & 0.15 & 0.21 \\
\hline & $G r \mathrm{CU}+C S$ & 99.95 & $87.83-112.57$ & $3.33 \pm 0.68$ & 4.89 & 0.16 & 0.23 \\
\hline & $T h \mathrm{CU}+C S$ & 94.46 & $83.07-104.90$ & $3.64 \pm 0.68$ & 5.29 & 0.13 & 0.45 \\
\hline & $S h \mathrm{CU}+F A$ & 101.49 & $88.80-115.29$ & $3.17 \pm 0.67$ & 4.68 & 0.17 & 0.13 \\
\hline & $G r \mathrm{CU}+F A$ & 130.63 & $119.34-143.30$ & $4.45 \pm 0.82$ & 5.40 & 0.13 & 0.35 \\
\hline & Th $\mathrm{CU}+F A$ & 92.61 & $80.02-103.52$ & $3.40 \pm 0.68$ & 4.98 & 0.15 & 0.17 \\
\hline & $S h \mathrm{CU}+A I$ & 71.20 & $61.98-79.81$ & $3.35 \pm 0.62$ & 5.39 & 0.13 & 0.27 \\
\hline & $G r \mathrm{CU}+A I$ & 70.71 & $61.58-79.15$ & $3.39 \pm 0.62$ & 5.45 & 0.12 & 0.22 \\
\hline & $T h \mathrm{CU}+A I$ & 75.98 & $62.79-90.17$ & $2.38 \pm 0.59$ & 3.97 & 0.24 & 0.14 \\
\hline \multirow{12}{*}{$96 \mathrm{~h}$} & $S h \mathrm{CU}+A S$ & 36.19 & $28.91-41.82$ & $3.12 \pm 0.51$ & 6.01 & 0.10 & 0.72 \\
\hline & $G r \mathrm{CU}+A S$ & 78.99 & $65.94-88.21$ & $3.83 \pm 0.72$ & 5.30 & 0.13 & 0.39 \\
\hline & $T h \mathrm{CU}+A S$ & 81.52 & $70.36-89.93$ & $4.21 \pm 0.73$ & 5.73 & 0.11 & 0.63 \\
\hline & $S h \mathrm{CU}+C S$ & 80.23 & $68.66-88.77$ & $4.15 \pm 0.73$ & 5.66 & 0.12 & 0.37 \\
\hline & $G r \mathrm{CU}+C S$ & 81.87 & $71.60-89.80$ & $4.50 \pm 0.74$ & 6.02 & 0.10 & 0.61 \\
\hline & $T h \mathrm{CU}+C S$ & 77.56 & $67.01-85.36$ & $4.64 \pm 0.76$ & 6.06 & 0.10 & 0.61 \\
\hline & $S h \mathrm{CU}+F A$ & 81.09 & $68.82-90.07$ & $3.92 \pm 0.72$ & 5.42 & 0.13 & 0.55 \\
\hline & $G r \mathrm{CU}+F A$ & 106.91 & $93.86-116.58$ & $4.70 \pm 0.83$ & 5.60 & 0.12 & 0.76 \\
\hline & $T h \mathrm{CU}+F A$ & 77.93 & $68.56-85.05$ & $5.12 \pm 0.79$ & 6.42 & 0.09 & 0.44 \\
\hline & $S h \mathrm{CU}+A I$ & 58.92 & $50.74-65.23$ & $4.23 \pm 0.68$ & 6.17 & 0.10 & 0.55 \\
\hline & $G r \mathrm{CU}+A I$ & 58.74 & $49.60-65.60$ & $3.85 \pm 0.66$ & 5.80 & 0.11 & 0.37 \\
\hline & $T h \mathrm{CU}+A I$ & 59.82 & $50.60-66.80$ & $3.77 \pm 0.66$ & 5.71 & 0.11 & 0.52 \\
\hline
\end{tabular}

Six batches of 10 snails were exposed different concentration of the above molluscicides with different breeds of cow urine. Significant negative regression $(\mathrm{P}<0.05)$ was observed between exposure time and $\mathrm{LC}_{50}$ of treatments. Ts-testing significant of the regression coefficient: ShCU+AS-16.24 ${ }^{+}$;

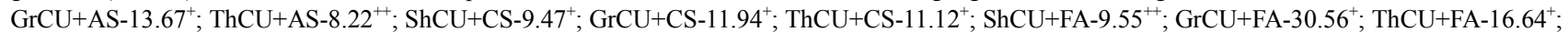
ShCU+AI-9.30 $0^{+}$GrCU+AI-16.34+ ${ }^{+}$ThCU+AI-15.12 . +: linear regression between $x$ and $y$; ++: non-linear regression between log $x$ and $\log y$. Abbreviation; Sh Sahiwal, Gr Geer, Th Tharparkar, AS Annona squamosa, CS Camellia sinensis FA Ferula asafoetida, AI Azadirachta indica. 
2- Sahiwal, Geer and Tharparkar cow urine kept for 15 in laboratory condition.

3- Binary combinations (1:1) of plant molluscicides such as Annona squamosa (Annonaceae) seed powder, Azadirachta indica (Meliaceae) oil, Ferula asafoetida (Apiaceae) root latex and Camellia sinensis (Theaceae) leaf with freeze dried cow urine (FCU) of different breeds cow urine kept for 15 days in laboratory and sun light ( $8 \mathrm{~h} /$ days).
Plants used in this works were collected locally, and identified at the herbarium of the Botany Department, DDU Gorakhpur University, Gorakhpur, India where voucher herbarium specimens (\# No 3228 for Annona squamosa and 3815 for Ferula asafoetida) are on deposit. A. Indica oil was obtained from Indian Herbs Saharanpur, UP, India. Annona Squamosa seed powders were prepared by using the methods of Singh and Singh (2001).

\subsection{Plants Used}

Table 2. Toxicity of freeze-dried cow urine (FCU) kept for 15 days in laboratory condition of different breeds of cow Sahiwal, Geer, Tharparkar and its binary combination (1:1) with $A$. squamosa, C. sinensis, F. asafoetida and A. indica against L. acuminata at different exposure period.

\begin{tabular}{|c|c|c|c|c|c|c|c|}
\hline Exposure period & Treatment & $\mathrm{LC}_{50} \mathrm{mg} / \mathrm{l}(\mathrm{w} / \mathrm{v})$ & Limits LCL-UCL & Slope value & t- ratio & g-value & Heterogeneity \\
\hline \multirow{12}{*}{$24 \mathrm{~h}$} & $S h \mathrm{CU}+A S$ & 81.40 & $70.87-101.26$ & $3.11 \pm 0.55$ & 5.62 & 0.12 & 0.16 \\
\hline & $G r \mathrm{CU}+A S$ & 132.95 & $111.89-192.10$ & $3.25 \pm 0.70$ & 4.62 & 0.17 & 0.29 \\
\hline & $T h \mathrm{CU}+A S$ & 151.50 & $133.20-192.81$ & $3.84 \pm 0.67$ & 5.06 & 0.15 & 0.23 \\
\hline & $S h \mathrm{CU}+C S$ & 118.90 & $102.98-155.77$ & $3.38 \pm 0.67$ & 5.00 & 0.15 & 0.24 \\
\hline & $G r \mathrm{CU}+C S$ & 148.19 & $130.34-188.32$ & $3.70 \pm 0.74$ & 4.98 & 0.15 & 0.29 \\
\hline & $T h \mathrm{CU}+C S$ & 153.48 & $133.96-199.83$ & $3.68 \pm 0.75$ & 4.90 & 0.16 & 0.20 \\
\hline & $S h \mathrm{CU}+F A$ & 136.09 & $115.07-192.37$ & $3.54 \pm 0.73$ & 4.84 & 0.16 & 0.22 \\
\hline & $G r \mathrm{CU}+F A$ & 141.15 & $127.39-166.56$ & $4.48 \pm 0.77$ & 5.78 & 0.11 & 0.23 \\
\hline & $T h \mathrm{CU}+F A$ & 125.47 & $108.25-166.64$ & $3.58 \pm 0.71$ & 5.05 & 0.15 & 0.29 \\
\hline & $S h \mathrm{CU}+A I$ & 111.99 & $97.91-142.28$ & $3.34 \pm 0.66$ & 5.07 & 0.14 & 0.11 \\
\hline & $G r \mathrm{CU}+A I$ & 107.13 & $94.31-132.89$ & $3.35 \pm 0.65$ & 5.16 & 0.14 & 0.20 \\
\hline & $T h \mathrm{CU}+A I$ & 90.67 & $75.25-130.36$ & $2.47 \pm 0.52$ & 4.68 & 0.17 & 0.12 \\
\hline \multirow{12}{*}{$48 \mathrm{~h}$} & $S h \mathrm{CU}+A S$ & 62.77 & $53.56-76.29$ & $2.41 \pm 0.48$ & 4.97 & 0.15 & 0.15 \\
\hline & $G r \mathrm{CU}+A S$ & 90.65 & $81.85-103.31$ & $3.80 \pm 0.63$ & 5.94 & 0.10 & 0.33 \\
\hline & $T h \mathrm{CU}+A S$ & 127.39 & $111.18-162.93$ & $2.82 \pm 0.68$ & 4.14 & 0.22 & 0.15 \\
\hline & $S h \mathrm{CU}+C S$ & 90.23 & $80.31-105.30$ & $3.27 \pm 0.62$ & 5.24 & 0.14 & 0.26 \\
\hline & $G r \mathrm{CU}+C S$ & 121.16 & $107.90-143.95$ & $3.28 \pm 0.68$ & 5.78 & 0.16 & 0.31 \\
\hline & $T h \mathrm{CU}+C S$ & 136.53 & $118.46-181.33$ & $2.89 \pm 0.69$ & 4.19 & 0.21 & 0.18 \\
\hline & $S h \mathrm{CU}+F A$ & 99.56 & $87.28-123.43$ & $2.99 \pm 0.62$ & 4.81 & 0.16 & 0.16 \\
\hline & $G r \mathrm{CU}+F A$ & 118.73 & $108.18-134.04$ & $4.16 \pm 0.71$ & 5.84 & 0.11 & 0.20 \\
\hline & $T h \mathrm{CU}+F A$ & 100.29 & $87.58-125.96$ & $2.90 \pm 0.62$ & 4.66 & 0.17 & 0.19 \\
\hline & $S h \mathrm{CU}+A I$ & 89.66 & $78.85-106.85$ & $2.94 \pm 0.61$ & 4.79 & 0.16 & 0.13 \\
\hline & $G r \mathrm{CU}+A I$ & 87.52 & $77.56-102.00$ & $3.15 \pm 0.61$ & 5.10 & 0.14 & 0.17 \\
\hline & $T h \mathrm{CU}+A I$ & 68.34 & $57.30-88.96$ & $2.14 \pm 0.48$ & 4.43 & 0.19 & 0.24 \\
\hline \multirow{12}{*}{$72 \mathrm{~h}$} & $S h \mathrm{CU}+A S$ & 44.44 & $35.69-51.82$ & $2.49 \pm 0.48$ & 5.19 & 0.14 & 0.29 \\
\hline & $G r \mathrm{CU}+A S$ & 82.30 & $72.99-94.06$ & $3.25 \pm 0.61$ & 5.26 & 0.13 & 0.42 \\
\hline & $T h \mathrm{CU}+A S$ & 91.93 & $76.40-104.69$ & $2.89 \pm 0.67$ & 4.29 & 0.20 & 0.21 \\
\hline & $S h \mathrm{CU}+C S$ & 69.04 & $58.83-77.96$ & $3.12 \pm 0.61$ & 5.08 & 0.14 & 0.22 \\
\hline & $G r \mathrm{CU}+C S$ & 121.16 & $107.90-143.95$ & $3.28 \pm 0.68$ & 5.78 & 0.16 & 0.31 \\
\hline & $T h \mathrm{CU}+C S$ & 91.15 & $80.48-100.42$ & $3.96 \pm 0.70$ & 5.66 & 0.12 & 0.38 \\
\hline & $S h \mathrm{CU}+F A$ & 75.41 & $64.50-87.42$ & $2.94 \pm 0.60$ & 4.45 & 0.19 & 0.19 \\
\hline & $G r \mathrm{CU}+F A$ & 97.59 & $86.92-108.05$ & $3.80 \pm 0.69$ & 5.50 & 0.12 & 0.14 \\
\hline & $T h \mathrm{CU}+F A$ & 72.55 & $62.46-82.24$ & $3.06 \pm 0.61$ & 4.99 & 0.15 & 0.20 \\
\hline & $S h \mathrm{CU}+A I$ & 66.79 & $56.29-75.43$ & $3.13 \pm 0.61$ & 5.06 & 0.15 & 0.24 \\
\hline & $G r \mathrm{CU}+A I$ & 68.49 & $58.18-77.34$ & $3.12 \pm 0.61$ & 5.07 & 0.14 & 0.15 \\
\hline & $T h \mathrm{CU}+A I$ & 46.85 & $38.21-54.60$ & $2.48 \pm 0.48$ & 5.17 & 0.14 & 0.30 \\
\hline \multirow{12}{*}{$96 \mathrm{~h}$} & $S h \mathrm{CU}+A S$ & 34.30 & $26.77-39.98$ & $3.09 \pm 0.52$ & 5.91 & 0.11 & 0.52 \\
\hline & $G r \mathrm{CU}+A S$ & 67.79 & $59.02-75.44$ & $3.60 \pm 0.63$ & 5.69 & 0.11 & 0.44 \\
\hline & $T h \mathrm{CU}+A S$ & 75.76 & $63.35-84.42$ & $4.16 \pm 0.75$ & 5.53 & 0.12 & 0.59 \\
\hline & $S h \mathrm{CU}+C S$ & 57.48 & $49.96-63.29$ & $4.65 \pm 0.65$ & 6.47 & 0.09 & 0.48 \\
\hline & $G r \mathrm{CU}+C S$ & 80.89 & $68.84-89.76$ & $3.99 \pm 0.72$ & 5.54 & 0.12 & 0.29 \\
\hline & $T h \mathrm{CU}+C S$ & 80.00 & $69.28-88.04$ & $4.44 \pm 0.75$ & 5.89 & 0.11 & 0.88 \\
\hline & $S h \mathrm{CU}+F A$ & 58.18 & $48.49-65.30$ & $3.70 \pm 0.66$ & 5.58 & 0.12 & 0.48 \\
\hline & $G r \mathrm{CU}+F A$ & 77.52 & $66.87-85.36$ & $4.62 \pm 0.76$ & 6.03 & 0.10 & 0.33 \\
\hline & $T h \mathrm{CU}+F A$ & 56.16 & $47.09-62.80$ & $4.03 \pm 0.68$ & 5.86 & 0.11 & 0.47 \\
\hline & $S h \mathrm{CU}+A I$ & 56.73 & $48.46-62.95$ & $4.34 \pm 0.70$ & 6.19 & 0.10 & 0.39 \\
\hline & $G r \mathrm{CU}+A I$ & 55.37 & $46.55-61.83$ & $4.18 \pm 0.70$ & 5.98 & 0.10 & 0.42 \\
\hline & $T h \mathrm{CU}+A I$ & 35.95 & $28.44-41.69$ & $3.05 \pm 0.51$ & 5.90 & 0.11 & 0.74 \\
\hline
\end{tabular}

Six batches of 10 snails were exposed different concentration of the above molluscicides with different breeds of cow urine. Significant negative regression $(\mathrm{P}<0.05)$ was observed between exposure time and $\mathrm{LC}_{50}$ of treatments. Ts-testing significant of the regression coefficient: ShCU+AS-10.98 $8^{+}$; GrCU+AS-10.44 ${ }^{++}$; ThCU+AS-10.49 ; ShCU+CS-10.78 ${ }^{++}$; GrCU+CS-3.88 ${ }^{+}$ThCU+CS-5.87 ${ }^{+}$; ShCU+FA-8.93 ${ }^{++}$; GrCU+FA-57.01 ${ }^{+}$; ThCU+FA-13.84 ${ }^{+}$; ShCU+AI-8.74 ${ }^{+}$GrCU+AI-15.94 ${ }^{+}$ThCU+AI-9.59 ${ }^{+}$. +: linear regression between $x$ and $y$; ++: non-linear regression between log $x$ and log $y$. Abbreviation; Sh Sahiwal, Gr Geer, Th Thaparkar, AS Annona squamosa, CS Camellia sinensis FA Ferula asafoetida, AI Azadirachta indica. 


\subsection{Test Animal}

The adult snails Lymnaea acuminata $(2.60 \pm 0.30 \mathrm{~cm}$ length) were collected from the local ponds and pools in Gorakhpur. The collected snails were storage $72 \mathrm{~h}$ in laboratory condition for acclimatized before the treatment.

\subsection{Experiment}

Toxicity experiment was performed by the methods of Singh and Agarwal (1984). Ten experimental animals were kept in a glass aquaria containing 3 liter of dechlorinated tap water at $22^{\circ} \mathrm{C}$ to $24^{\circ} \mathrm{C}$. The $\mathrm{pH}$ of the water was $7.1-7.3$ and dissolved oxygen, free carbon dioxide and bicarbonate alkalinity were $6.5-7.2 \mathrm{mg} / 1,5.2-6.3 \mathrm{mg} / 1$ and $102.0-105.0$ $\mathrm{mg} / \mathrm{l}$, respectively. Dead animals were removed immediately from the aquaria to avoid any contamination. Snails were exposed to binary combinations (1:1) of plant derived molluscicides such as $A$. squamosa seed powder, $A$. indica oil, $F$. asafoetida root latex and $C$. sinensis with freeze-dried powder (FCU) of different breeds cow urine kept for 15 days in laboratory condition or sun light $(8 \mathrm{~h} /$ days $)$. Six aquaria were set up for each concentration. Mortality was recorded at $24 \mathrm{~h}$ interval up to $96 \mathrm{~h}$ exposure period. Snail mortality was established by contraction of the body within the shell and absence of response to a needle probe was taken as evidence of death.

\subsection{Statistical Analysis}

Lethal concentration value $\left(\mathrm{LC}_{50}\right)$ upper and lower confidence limits (UCL and LCL) and slope value, t-ratio, g-value, and heterogeneity were calculated according to the POLO computer programme of Robertson et al., (2007). The regression coefficient was determined between exposure time and different values of $\mathrm{LC}_{50}$ (Sokal and Rohlf 1973).

\subsection{Result}

The fresh cow urine of different breeds of cow was pale yellow in colour, it kept for 15 days in sun light ( $8 \mathrm{~h} /$ day) the colour was converted into dark brown, while it kept for 15 days in laboratory condition it light brown in colour. Toxicity of binary combination (1:1) of plant molluscicides and freeze-dried cow urine (FCU) of different breeds of cow such as Sahiwal, Geer, and Tharparkar kept for 15 days in sunlight (8h/day) and laboratory condition against snail $L$. acuminata was time and concentration dependent.

The toxicity of binary combination (1:1) of Sahiwal freeze-dried cow urine $+A$. squamosa kept for 15 days in sunlight ( $8 \mathrm{~h} /$ day) $\left(24 \mathrm{~h} \mathrm{LC}_{50}-97.27 \mathrm{mg} / \mathrm{l}\right)$ was more effective than the Geer $\left(24 \mathrm{~h} \mathrm{LC}_{50}-148.04 \mathrm{mg} / \mathrm{l}\right)$ and Tharparkar freeze-dried cow urine $\left(24 \mathrm{~h} \mathrm{LC}_{50}-158.06 \mathrm{mg} / \mathrm{l}\right)$, respectively (Table-1). Binary combination of Sahiwal freeze-dried cow urine $+A$. squamosa $\left(24 \mathrm{~h} \mathrm{LC}_{50}-81.40 \mathrm{mg} / \mathrm{l}\right)$ kept for 15 days in laboratory condition was more toxic than Geer $\left(24 \mathrm{~h} \mathrm{LC}_{50}\right.$ $-132.95 \mathrm{mg} / \mathrm{l})$ and Tharparkar $\left(24 \mathrm{~h} \mathrm{LC}_{50}-151.50 \mathrm{mg} / \mathrm{l}\right)$, respectively (Table-1). Toxicity of $96 \mathrm{~h} \mathrm{LC}_{50}$ of Sahiwal freeze-dried cow urine $+A$. squamosa $\left(96 \mathrm{LCC}_{50}-34.30 \mathrm{mg} / \mathrm{l}\right)$ kept for 15 days in laboratory condition is more toxic than the other breed of cow (FCU) (Table-2). The $24 \mathrm{~h} \mathrm{LC}_{50}$ of Tharparkar cow urine kept for 15 days in sunlight and laboratory condition with $F$. asafoetida $(132.87 \mathrm{mg} / \mathrm{l}$ and $125.47 \mathrm{mg} / \mathrm{l})$ was lower than the Sahiwal $(159.22 \mathrm{mg} / \mathrm{l}$ and $136.09 \mathrm{mg} / \mathrm{l})$ and Geer $(183.31 \mathrm{mg} / \mathrm{l}$ and $141.15 \mathrm{mg} / \mathrm{l})$ cow urine kept for 15 days in sunlight and laboratory condition, respectively (Table-1,2).

The other binary combination of Sahiwal cow urine kept for 15 days in sunlight with $A$. indica oil $\left(24 \mathrm{~h} \mathrm{LC}_{50}\right.$ $-118.81 \mathrm{mg} / \mathrm{l}$ and $\left.96 \mathrm{~h} \mathrm{LC}_{50}-58.92 \mathrm{mg} / \mathrm{l}\right)$ Tharparkar cow urine $+A$. indica oil $\left(24 \mathrm{~h} \quad \mathrm{LC}_{50}-120.02 \mathrm{mg} / \mathrm{l}\right.$ and $96 \mathrm{~h}$ $\left.\mathrm{LC}_{50}-59.82 \mathrm{mg} / \mathrm{l}\right)$ and Geer cow urine $+A$. indica oil $(24 \mathrm{~h}$ $\mathrm{LC}_{50}-119.30 \mathrm{mg} / 1$ and $96 \mathrm{~h} \mathrm{LC}_{50}-58.74 \mathrm{mg} / \mathrm{l}$ ), respectively almost similar have same toxicity against $L$. acuminata. Tharparkar cow urine kept for 15 days in sun light with $C$. sinensis $\left(24 \mathrm{~h} \mathrm{LC}_{50}-150.18 \mathrm{mg} / \mathrm{l}\right)$ was more effective than the Sahiwal $\left(24 \mathrm{~h} \mathrm{LC}_{50}-161.62 \mathrm{mg} / \mathrm{l}\right)$ and Geer cow urine $(24 \mathrm{~h}$ $\mathrm{LC}_{50}-159.09 \mathrm{mg} / \mathrm{l}$ ), respectively (Table- 2 ).

The slope values were steep and separate estimation of LC based on each of the six replicates was found to be within $95 \%$ confidence limits of $\mathrm{LC}_{50}$. The t- ratio was greater than 1.96 and the heterogeneity factor is less than 1.0. The g- value was less than 0.5 at all probability levels (90, 95 and 99).

\section{Discussion}

The result clearly demonstrate that the freeze-dried cow urine (FCU) of different Indian breeds kept for 15 days in sunlight ( $8 \mathrm{~h} /$ day) and laboratory condition and its binary combination (1:1) with plant molluscicides such as $A$. squamosa seed powder, A. indica oil, F. asafoetida root latex and $C$. sinensis leaf are potent molluscicide. It has been reported by various scientist that cow urine fermented and distillate cow urine cause insecticidal, fungicidal, antimicrobial, antihelmintic and molluscicidal activity (Adane and Gautam, 2003; Tripathi et al., 2006; Kalkude, et al., 2010; Kumar et al., 2011). Urea is major component present in urine and is the end product of protein metabolism (Kumar et al. 2011). It is a strong antibacterial agent. Similarly, uric acid is also present in urine is a strong antibacterial. It may be possible that in the present study cow urine also acts as bio-enhancer with the plant products so that the active molluscicidal components of these plants reaches higher titer in snail body. It was natural disinfectant and anti-septic qualities. In traditional medicines cow urine was consumed as an effective and simple medicine. It contains 24 types of salt as well as iron, calcium, phosphorus, carbonic acid, potash and lactose. Its main constituent show disinfectant activity is carbolic acid, which is mixture of phenol and cresol (Kelly, 1997, Khanuja et al., 2002).

Cow urine kept for 15 days in sunlight (8h/day) and laboratory condition of Sahiwal + A. squamosa $\left(96 \mathrm{~h} \mathrm{LC}_{50}\right.$ $-36.19 \mathrm{mg} / \mathrm{l}$ and $34.30 \mathrm{mg} / \mathrm{l}$ ) was more toxic than the other combination. It has been reported that the toxicity of anno- 
naceous acetogenins found cytotoxic and antitumor activity (Fang et al., 1993). It behaves as bioenhancer and enhances the antimicrobial effect of antibiotics many fold (Khanuja et al., 2002). Adane and Gautam (2003) have been reported insecticidal and fungicidal activity of fermented cow urine. Cow urine distillate act as antimicrobial against clinical pathogens (Sathasiyam et al., 2010). Tripathi et al., (2010) have been reported that the sublethal doses of cow urine and their formulation with plant derived molluscicides caused a significant reduction in fecundity, hatchability and survival of snail L. acuminata. Mikolajczak et al., (1989) annonaceous acetogenins using for the control of pest. In the present observation the toxicity of Sahiwal cow urine kept for 15 days in sunlight and laboratory condition with squamosa is more pronounced at $96 \mathrm{~h}$ exposure period. It indicate that the cow urine prolong and enhance the toxicity of A. squamosa up to $96 \mathrm{~h}$, while other binary combination Geer cow urine kept for 15 days in sunlight and laboratory condition with $A$. indica oil $\left(96 \mathrm{~h} \quad \mathrm{LC}_{50}-58.74 \mathrm{mg} / \mathrm{l}\right.$, $55.37 \mathrm{mg} / \mathrm{l}$ ), respectively were more toxic than other combination. The active component of $A$. indica oil is azadirachtin, toxic to the snail $L$. acuminata was effective only 24h (Singh et al., 1996b). Azadirachtin, the active component of Azadirachta indica, is not stable in water after $24 \mathrm{~h}$ (Szeto and Wan, 1996). Increase in the toxicity of binary combination of urine of different breeds of cow urine with plant molluscicides may be due to the inhibition of enzyme which detoxify the active molluscicidal agents in plants or it may be possible that in binary combination of two molluscicidal components act at different sites in the snail body which ultimately result come in higher toxicity against the snail L. acuminata.

It is evident that the steep slope value that a small increase in the binary combination of plant derived molluscicides such as $A$. squamosa seed powder, $A$. indica oil, $F$. asafoetida root latex and $C$. sinensis with freeze-dried powder of different breeds cow urine kept for 15 days laboratory and sun light $8 \mathrm{~h} /$ days was causes a higher mortality in snail. A t- ratio value greater than 1.96 indicates that the regression is significant. Heterogeneity factor value is less than 1.0 denoted that in the replicate test of random sample, the concentration response line would fall within $95 \%$ confidence limits and thus the model fits our data adequately. The index of significant of protein estimation g-value indicates that the value of mean is within the limits at all probability level (90, 95 and $99 \%)$.

Present studies demonstrate that the different breeds of freeze-dried cow urine (FCU) and plant molluscicides are potent molluscicides. They kill the intermediate host of Fasciola hepatica and Fasciola gigantica. This concept is an advanced safe technology for the control of harmful snail without spending more active molluscicides directly in the aquatic environment.

\section{ACKNOWLEDGMENTS}

One of the authors (Shiv Kumar) is thankful to Rajiv-
Gandhi National Fellowship (RJNF), University Grants Commission (UGC), and New Delhi letter No. F. 14-2(SC) /2010 (SA-III) for financial assistance.

\section{REFERENCES}

[1] Adane, T. and R. D. Gautam, 2003. Traditional pest management practices and lesser exploited natural products in Ethopia and India; Appraisal and revalidation. Indian J. Traditional Knowledge, 2:189-201

[2] Agarwal, R. A. and D. K. Singh, 1988. Harmful gastropods and their control. Acta Hydrochimia et Hydrobiologica., 16: $113-138$

[3] Estaben, J. G., M. D. Bargues and S. Mas-Coma, 1998. Geographical distribution, diagnosis and treatment of human fascioliasis: A review. Res Rev Parasitol., 58:13-42

[4] Fang, X., M.J. Rieser, Z. Gu, G. Zhao and J.L. McLaughlin, 1993. Annonaceous acetogenins; an updated review, Phytocheml Anal 4: 27-49.

[5] Jarald, E., S. Edwin, V. Tiwari, R. Garg and E. Toppo, 2008. Antioxidant and antimicrobial activities of cow urine. Global J Pharmacol. 2(2): 20-22

[6] Jigyasu, H. V. and V. K. Singh, 2010. Effect of certain environmental factors on the reproduction of snail Lymnaea acuminata. Journal of Water and Health, 8(1): 109-115

[7] Kelkuda, P. T. R., B. C. Nishanth, P. S. V. Kumar, D. Kamal, M. Sandeep and I. I. K. Meghraj, 2010. Cow urine concentrate: A potent agent with antimicrobial and antihelmintic activity. Drug Invention Today, 3(5): 1025-1027

[8] Kelly, J. F., 1997. The urine crude and other curious medical treatment.

http:// wfmu.org/LCD/Articles/LCD-19/urine.html

[9] Khanuja, S.P.S. et al., 2002. Assignee: Council of Scientific and Industrial Research New Delhi, India. Pharmaceutical Composition Containing Cow Urine Distillate and Antibiotic. (United States Patent. 6,410,059,)

[10] Krishnamurthi, K., D. Dutta, S. D. Sivanesan, and T. Chakrabti, 2004. Protective effect of distillate and redistillate of cow's urine in human polymorphonuclear leukocytes challenged with established genotoxic chemicals. Biomedical and environmental science, 17: 247-256

[11] Kumar, S., D. K. Singh and V. K. Singh, 2011. Molluscicidal effect of freeze-dried cow urine of Indian cow breeds against Lymnaea acuminata. American-Eurasian J of Toxicological Sciences, 3(2): 70-74

[12] Mas-Coma, S., J. G. Esteban and M. D. Bargues, 1999. Epidemiology of human fascioliasis: a review and proposed new classification. Bull WHO,77: 340-346

[13] Mas-Coma, S., M. A., Valero and M. D. Bargues, 2009. Fasciola, Lymnaeids and human fascioliasis with a global overview on disease transmission, Epidemiology, evolutionary genetics. Molecular Epidemiology and control. In: David Rollinson and Simon Iain Hay, Editors: Advances in Parasitology, Burlington: Academic Press 2009; 69: 141-146 
[14] Mas-Coma, S., M. D. Bargues and M. A. Valero, 2005. Fascioliasis and other .plant-borne trematode zoonoses. Int. Parasitol., 35: 1255-1278

[15] Mikolajczak, K. L., J. L. McLaughlin and J. K. Rupperch, 1989. Control of pest with Annonaceous acetogenins. US Patent No, 4, 855, 319

[16] Robertson, J. L., R. M. Russell, H. K. Preisler and N. E. Savin, 2007. Bioassay with arthropods. POLO computer programme for analysis of bioassay data. 2nd Edition, Talor and Francis, CRC Press, pp1-224

[17] Sathasiyam, A., M. Muthuselyam and R. Rajendran, 2010. Antimicrobial activities of cow urine distillate against some clinical pathogens. Global J Pharmacol., 4(1):41:44

[18] Shafer, T. J., D. A. Meyer, K. M. Crofton, 2005. Developmental neurotoxicity of pyrethroid insecticides: critical review and future research needs. Environ. Health Persp, 113: 123-136

[19] Singh, A. and D. K. Singh, 2001. Molluscicidal activity of the custard apple (A. squamosa L.) alone and in combination with other plant-derived molluscicides. J. of Herbs, Spices and Medicinal Plants, 8(1): 23-29

[20] Singh, A., D. K. Singh, T. N. Misra, and R. A. Agarwal, 1996a. Molluscicides of plants origin. Bio Agric Hortic., 13; 205-252

[21] Singh, D. K. and R. A. Agarwal, 1984. Correlation of the anticholinesterase and molluscicidal activity of the latex of the Euphorbia royleana Bioss on Lymnaea acuminata. J Natural Products, 47: 702-705

[22] Singh, K., A. Singh and D. K. Singh, 1996b. Molluscicidal activity of neem (Azadirachta indica A Juss) J. of Ethnopharmacology, 52: 35-40

[23] Singh, O. and R. A. Agarwal, 1981. Toxicity of certain pesticides to two economic species of snails in northern India. J. Econ., 14; 568-571

[24] Sokal, R. R. and F. J. Rohlf, 1973. Introduction to Biostatistics, Freeman, W. H. San Francisco.

[25] Sridhar, S., S. Arumugasamy, H. Saraswathy, and K. Vijayalakshmi, 2002. Organic Vegetable Gardening: First Edition. Centre for Indian Knowledge Systems, Chennai

[26] Szeto, S. Y. and M. Y. Wan, 1996. Hydrolysis of azadirachtin in buffered and natural water Proc. $4^{\text {th }}$ Int Neem Conf. $\mathrm{pp}^{4}$

[27] Tripathi, R., P. Kumar, V. K. Singh and D. K. Singh, 2010. Cow urine and their formulations with plant molluscicide against the reproduction of vector snail Lymnaea acuminata. Drug Invention Today, 2(8) : 376-380

[28] Tripathi, R., V. K. Singh and D. K. Singh, 2006. Freeze-dried powder of cow urine reduces the viability of the snail Lymnaea acuminata. J. Pest. Science, 79: 143-148 